\title{
Effect of fertilization date and litter removal on grassland forage production
}

\author{
BRIAN M. WIKEEM, REG F. NEWMAN, AND A.L. van RYSWYK
}

\begin{abstract}
The effects of application dates of urea fertilizer and dormantseason removal of litter were examined on a bluebunch whent grass (Pseudoroegneria spicatum [Pursh] A. Löve subsp. spicata) Sandberg's bluegrass (Poa sandbergid Vasey) site in southern British Columbin. Forest grade urea, applied at $100 \mathrm{~kg} \mathrm{~N} / \mathrm{hn}$, increased the yield of both spring $(53 \%)$ and summer $(73 \%)$ forage compared to the unfertilized control. Spring forage production was not affected by the application date of urea. Summer forage yields, however, were $20 \%$ higher when urea was applied on snow-free (October and March) compared to snow-covered eround (November, January, and February). Dormant-season removal of litter reduced spring forage yields by different amounts $(P<0.05)$ in 1984 (29\%) and 1981 (25\%). Albiet a small difference, this suggests that removal of litter may interact with annual weather conditions and confound measurements of absolute spring herbage yields in a longterm study. In contrast, dormant-season removal of litter reduced summer forage production consistently by $23 \%$ in both 1981 and 1984. This technique might therefore be used to reduce clipping time for summer plots in fertilizer trials. If absolute estimates of above ground herbage production are required, control plots should be clipped each year to account for the losses in yields induced by dormant-season removal of litter.
\end{abstract}

Key Words: urea, bluebunch wheatgrass, nitrogen, precipitation, cool season grasses, clipping

Fertilization research on British Columbia (B.C.) grasslands has focused primarily on application rates, site specific response, and residual effects of $\mathbf{N}$ fertilizers (Mason and Miltimore 1959, Kilcher et al. 1965, Hubbard and Mason 1967, Mason and Miltimore 1969, Mason and Miltimore 1972). In Oregon, Sneva (1973) reported equal response for fall, winter, and spring applications of urea and ammonium nitrate on standard crested wheatgrass (Agropyron desertorum (Fisch. ex Link) Schult) and Siberian wheatgrass (Agropyron sibiricum (L.) Beauv.). Similarly, Hull (1963) found no significant difference in pubescent wheatgrass (Thinopyrum intermedium subsp. barbulatum [Schur]) yields between spring and fall applications of ammonium nitrate on high elevation ranges in northeastern Utah. No information is available on the effect of different dates of fertilizer application on grasslands in B.C.

Separating litter from the current annual growth in a clipping study can be tedious and time consuming. In order to reduce clipping time, some researchers have removed the standing dead phytomass from bunchgrasses before spring growth commences by mowing the experimental site during the dormant period (Mason and Miltimore 1964, Wilson et al. 1966).

The removal of standing litter after plant senescence reduces plant growth in the following year, and consequently, may itself be considered a treatment. For example, Sauer (1978) found that bluebunch wheatgrass (Pseudoroegneria spicatum [Pursh] A. Love subsp. spicata) yields were reduced by $28 \%$ when quiescent

Authors are range scientist and assistant range scientist, Research Branch, British Columbia Ministry of Forests; and research scientist, Agriculture Canada, Agriculture Canada Research Station, 3015 Ord Road, Kamloops, B.C. V2B 8A9.

Manuscript accepted 26 January 1989. plants were clipped to the crowns in January. In a second study, bluebunch wheatgrass biomass was reduced $42 \%$ the following season when plants were clipped in September (McShane and Sauer 1985). Similarly, Willms et al. (1986) showed that rough fescue (Festuca scabrella Torr. var. major Vasey) yields on a Mixed Prairie site in southern Alberta were reduced by $25 \%$ after litter was removed during fall before winter dormancy.

True estimates of above-ground biomass only can be determined if the reductions in yields resulting from litter removal is consistent across all levels of other experimental treatments and can be accounted for in the experiment. The purposes of this research were to determine (1) the appropriate season and date to fertilize mid-elevation grassland sites in B.C., (2) the effects of applying urea on snow compared to bare ground and (3) the effects of dormant-season removal of litter, combined with other treatments, on subsequent spring and maximum (summer) above-ground herbage production.

\section{Study Area and Methods}

The study site is located $6 \mathrm{~km}$ north of Kamloops, B.C. $\left(50^{\circ} 44^{\prime}\right.$ $\mathrm{N}, 120^{\circ} 24^{\prime} \mathrm{W}$ ), in a bluebunch wheatgrass-Sandberg's bluegrass (Poa sandbergii Vasey) habitat type (Tisdale 1947, Table 1). The

Table 1. Mean percent frequency (per $20 \times 50 \mathrm{~cm}$ plot) of plant species found on the study site.

\begin{tabular}{|c|c|}
\hline Species & Frequency (\%) \\
\hline $\begin{array}{l}\text { Grasses } \\
\text { Pseudoroegneria spicatum } \\
\text { Koeleria cristata } \\
\text { Poa sandbergii } \\
\text { Festuca scabrella }\end{array}$ & $\begin{array}{r}36.8 \\
7.5 \\
18.4 \\
1.0\end{array}$ \\
\hline $\begin{array}{l}\text { Forbs } \\
\text { Achillea millefolium } \\
\text { Antennaria parvifolia } \\
\text { Antennaria dimorpha } \\
\text { Arabis holboellii } \\
\text { Astragalus collinus } \\
\text { Crepis atrabarba } \\
\text { Draba nervosa } \\
\text { Draba verna } \\
\text { Erigeron filifolius } \\
\text { Erigeron spp. } \\
\text { Fritillaria pudica } \\
\text { Lomatium macrocarpum } \\
\text { Microseris gracilis } \\
\text { Taraxacum officinale } \\
\text { Tragopogon dubius }\end{array}$ & $\begin{array}{l}3.0 \\
1.4 \\
3.1 \\
T \\
0.5 \\
T \\
2.2 \\
0.5 \\
T \\
1.8 \\
T \\
T \\
0.7 \\
T \\
T\end{array}$ \\
\hline $\begin{array}{l}\text { Shrubs } \\
\text { Artemisia frigida } \\
\text { Artemisia tridentata } \\
\text { Eriogonum heracleoides }\end{array}$ & $\begin{array}{l}0.7 \\
T \\
T\end{array}$ \\
\hline $\begin{array}{l}\text { Others } \\
\text { Rock } \\
\text { Soil }\end{array}$ & $\begin{array}{c}\mathrm{T} \\
20.7\end{array}$ \\
\hline
\end{tabular}

$\mathrm{T}=\mathrm{Trace}$ (less than $0.5 \%$ frequency). 
Table 2. Soll conditions during fertilizer applleation and precipitation und temperatures for the week following fertilization.

\begin{tabular}{llcrrr}
\hline \hline \multirow{2}{*}{$\begin{array}{l}\text { Applica- } \\
\text { tion date }\end{array}$} & $\begin{array}{c}\text { Soil surface } \\
\text { Conditions }\end{array}$ & Rain & Snow & Total & $\begin{array}{c}\text { Tempera- } \\
\text { ture }\end{array}$ \\
\cline { 3 - 5 } & $1980-81$ & $(\mathrm{~mm})$ & $(\mathrm{cm})$ & $(\mathrm{mm})$ & $\circ \mathrm{C}$ \\
Oct. & Moist, free water & 1.2 & 0.0 & 1.2 & 6.2 \\
Nov. & $20 \mathrm{~cm}$ snow, frozen & 0.0 & 31.6 & 21.8 & -6.8 \\
Jan. & $2 \mathrm{~cm}$ snow, frozen & $\mathrm{Tr}$ & 1.1 & 1.1 & -1.7 \\
Feb. & $7 \mathrm{~cm}$ snow, frozen & 1.8 & 4.2 & 5.0 & 7.3 \\
Mar. & moist, frozen & $\mathrm{Tr}$ & 0.0 & $\mathrm{Tr}$ & 7.1 \\
& $1983-84$ & & & & \\
Oct. & moist, free water & 2.3 & 0.0 & 2.3 & 9.5 \\
Nov. & $7 \mathrm{~cm}$ snow, frozen & 0.0 & 1.0 & 0.8 & -5.3 \\
Jan. & $20 \mathrm{~cm}$ snow, frozen & 3.0 & 2.0 & 4.9 & 0.7 \\
Feb. & $21 \mathrm{~cm}$ snow, frozen & 0.0 & 0.0 & 0.0 & 6.4 \\
Mar. & moist, free water & 7.3 & $\mathrm{Tr}$ & 7.3 & 10.5 \\
\hline
\end{tabular}

$\mathrm{Tr}=\mathrm{Trace}$

aspect at the site is northwest with a 3-5\% slope and the elevation is approximately $750 \mathrm{~m}$. The soil is an Orthic Dark Brown Chernozem (Typic Haploboroll) of aeolean origin with a fine sandy loam texture (pH $5.8\left(0.01 \mathrm{M} \mathrm{CaCl}_{2}\right)$, organic matter $2 \%$, Bray P 23 ppm). Mean annual precipitation at Kamloops is $256 \mathrm{~mm}$ with peaks in June-August and December-January (Atmospheric Environment Service 1984). The area has been moderately grazed by cattle using a deferred rest rotation system for the past 10 years, but the specific study site was ungrazed during the study because of restricted access.

Four blocks were layed out parallel to slope contours. Each block was divided in half (whole-plots) to accommodate the 2 years in the experiment. Factorial combinations of 2 treatments, FERTILIZATION and LITTER REMOVAL were randomly applied to $2 \times 2 \mathrm{~m}$ plots within each whole-plot. The FERTILIZATION treatment consisted of a single application of $100 \mathrm{Kg} \mathrm{N} / \mathrm{ha}$ of forest grade urea (45-0-0-0) at 5 dates and a control. Application dates of the fertilizer treatment in 1980-81 were 23 October, 28 November, 5 January, 12 February, and 19 March. In 1983-84, the fertilizer treatment was applied on 27 October, 29 November, 6 January, 16 February, and 21 March. Fertilizer was hand applied to bare ground in October and March, and onto snow in November, January and February in each year (Table 2).

Table 3. Comparisons of fornge production means using orthogonal contrasts.

\begin{tabular}{|c|c|c|c|c|}
\hline \multirow[b]{3}{*}{$\begin{array}{l}\text { Main effects } \\
\text { Fertilized vs. Unfertilized } \\
1981 \text { vs. } 1984 \\
\text { Fertilized on Snow vs. Bare Ground } \\
\text { Fertilized FALL1 vs. SPRING }{ }^{2} \\
\text { (Season) }\end{array}$} & \multicolumn{2}{|c|}{ Spring harvest } & \multicolumn{2}{|c|}{ Summer harvest } \\
\hline & & $-\mathbf{k g}$ & (ho & \\
\hline & $\begin{array}{l}270 \\
128 \\
264 \\
263\end{array}$ & $\begin{array}{l}176 * \\
381 * \\
280 \\
187\end{array}$ & $\begin{array}{l}1401 \\
1470 \\
1302 \\
1460\end{array}$ & $\begin{array}{r}809 * \\
1130 * \\
1551 * \\
1362\end{array}$ \\
\hline Litter Removal vs. NO Removal & 214 & $297 *$ & 1133 & $1470 *$ \\
\hline $\begin{array}{l}\text { Interactions } \\
\text { Year } \times \text { Litter Removal } \\
\text { Year } \times \text { Fertilized } \\
\text { Year } \times \text { Snow-Covered } \\
\text { Year } \times \text { Season-of-N-Application } \\
\text { Litter Removal } \times \text { Fertilized } \\
\text { Litter Removal } \times \text { Snow Covered } \\
\text { Litter Removal } \times \text { Season-of-N- } \\
\quad \text { Application }\end{array}$ & & & & $\begin{array}{l}\text { NS } \\
\text { NS } \\
\text { NS } \\
\text { NS } \\
\text { NS } \\
\text { NS } \\
\text { NS }\end{array}$ \\
\hline
\end{tabular}

* Means significantly different at $P<0.05$.

'FALL = October and November

2SPRING = February and March
The LITTER REMOVAL treatment was applied to one-half of the fertilized plots and the remaining plots were left untreated. Litter removal took place in mid-October of 1980 and 1983 following senescence of bluebunch wheatgrass. Plots were hand clipped and the harvested material was spread over each of the $2-\times 2-\mathrm{m}$ plots. Spring and summer forage production data were collected each year by clipping a 1-X $1-\mathrm{m}$ area located centrally within each plot.

Spring forage production was determined by clipping one-half of the total number of plots annually on 22 April 1981 and 16 May 1984 when bluebunch wheatgrass tillers reached $20 \mathrm{~cm}$. These dates correspond to the recommended height required for spring grazing in the Kamloops area (McLean and Marchand 1968). In order to determine maximum forage production, the remaining plots were harvested in August following seed set of bluebunch wheatgrass. Plants were clipped to a 5-cm stubble height and the litter was discarded where applicable. Herbage samples were oven dried at $70^{\circ} \mathrm{C}$ for $48 \mathrm{~h}$ and weighed.

The experimental design was a randomized complete block with a split-plot in time. Spring and summer forage production were analyzed separately with analysis of variance using SAS PROC GLM (SAS 1979). Means were tested for differences using orthogonal contrasts at $P<0.05$.

\section{Results and Discussion}

\section{Spring Harvest}

Averaged over both years, urea fertilization increased $(P<0.05)$ spring forage production by $53 \%$ compared to the unfertilized control. Yields in 1984, were nearly triple those in 1981 (Table 3) reflecting the higher spring precipitation in 1984 (Table 4). A significant Year by Fertilized interaction (Table 3) showed that herbage responded substantially more to fertilizer in 1984 than 1981. Indeed, yields on fertilized plots increased by $69 \%$ in 1984 but only $19 \%$ in 1981 compared to the unfertilized controls.

Dormant-season removal of litter produced different effects on spring forage production in 1981 compared to 1984 as indicated by the significant Year by Litter Removal interaction in Table 3. In 1984 this treatment reduced spring forage yields by $29 \%$ compared to $25 \%$ in 1981 . These results suggest that the removal of standing litter of bluebunch wheatgrass when the plant is senescent may interact with annual weather conditions and confound measurements of absolute herbage yields in a long-term study. Additionally, these yield reductions may be further exacerbated if the treatment is repeated on the same plants over a number of years.

A significant Year by Season-of-N-Application interaction (Table 3 ) indicates that spring forage yields responded differently to the season of fertilizer application in each year. In 1981, forage production was $33 \%$ higher when urea was applied in FALL (October and November) as compared to SPRING (February and March). In 1984, however, this trend was reversed with SPRING fertilizer application yielding $\mathbf{2 8 \%}$ more forage production than

Table 4. March to July precipitation (mm) and mean temperatures $\left({ }^{\circ} \mathrm{C}\right.$ ) during 1981, 1984 and 85 year average for Kamloops, B.C.

\begin{tabular}{lccc}
\hline \hline Date & 1981 & 1984 & $\begin{array}{c}\text { 85 Year } \\
\text { average }\end{array}$ \\
\hline & & $-(\mathrm{mm})$ & \\
Mar.-Apr. & 22 & 37 & 20 \\
May-July & 126 & 72 & 70 \\
Total & 148 & 109 & 90 \\
& & $\left({ }^{\circ} \mathrm{C}\right)$ & \\
Mar.-Apr. & 8 & 8 & 6 \\
May-July & 17 & 17 & 18 \\
\hline
\end{tabular}


Table 5. Mean herbage yields (kg/ha) from spring and summer harvested plots as affected by date of $\mathbf{N}$ fertilization and litter removal treatment.

\begin{tabular}{|c|c|c|c|c|}
\hline \multirow[b]{2}{*}{$\begin{array}{l}\text { Date } \\
\text { Fertilized }\end{array}$} & \multicolumn{2}{|c|}{ Spring harvest } & \multicolumn{2}{|c|}{ Summer harvest } \\
\hline & $\begin{array}{c}\text { litter } \\
\text { removed }\end{array}$ & untreated & $\begin{array}{l}\text { litter } \\
\text { removed }\end{array}$ & untreated \\
\hline $\begin{array}{l}\text { Control } \\
\text { October } \\
\text { November } \\
\text { January } \\
\text { February } \\
\text { March }\end{array}$ & $\begin{array}{l}153 \\
215 \\
191 \\
169 \\
306 \\
247 \\
\end{array}$ & $\begin{array}{l}199 \\
325 \\
338 \\
291 \\
299 \\
340 \\
\end{array}$ & $\begin{array}{r}681 \\
1196 \\
1263 \\
1202 \\
1024 \\
1432 \\
\end{array}$ & $\begin{array}{r}938 \\
1825 \\
1579 \\
1521 \\
1242 \\
1752 \\
\end{array}$ \\
\hline $\bar{x}$ & 214 & 299 & 1133 & 1476 \\
\hline
\end{tabular}

FALL. No differences $(P>0.05)$ were found in spring forage production among individual urea application dates (Table 6) possibly because the fertilizer was not fully depleted by the time the plots were harvested. There was no significant Litter Removal by Fertilized interaction (Table 3 ) indicating that fall litter removal affected both the fertilized and unfertilized plots equally.

\section{Summer Harvest}

Fertilization increased the average yield of summer forage by 73\% compared to the control (Table 3). In contrast to spring forage, mean forage production at the end of the growing season was lower in 1984 than in 1981 (Table 6) corresponding to drier growing conditions during May-July in 1984 (Table 4).

Although there was no difference in forage production between FALL and SPRING $\mathbf{N}$ application dates, herbage yields were nearly $20 \%$ higher when urea was applied on bare ground compared to snow (Table 3). Moreover, an insignificant Year by SnowCovered interaction (Table 3) indicates that the response was consistent between years. In agreement with our results, Campbell et al. (1986) concluded that $\mathrm{N}$ efficiency was lowest when ammonium nitrate and urea were applied to 6 dryland grass species on snow-covered soils in Saskatchewan. Losses, however, appeared to be greatest on the plots fertilized with ammonium nitrate compared to urea. Our results, however, do not agree with Sneva (1973) who found that forage yields were unaffected when urea was applied to deep snow compared to bare soil on rangeland. Wullstein and Gilmour (1964) attributed losses of N, applied on deep snow, to gaseous processes presumably resulting from the dissociation of urea in the snow to ammonia and the rapid evaporation of the snow to the air. Once urea penetrates the soil, however, losses of ammonia are reduced (Tisdale and Nelson 1975).

The specific mechanism for $\mathrm{N}$ losses in this study are not known but likely relate to rapid snow-melt on the site. For example, mean summer forage production was lower $(P<0.05)$ for the February application date than for October and March (Table 6). Most of this difference, however, occurred in 1981 when there was a sudden increase in average daily maximum temperatures from $-1.4^{\circ} \mathrm{C}$ for the 5-day period before application to $13.8^{\circ} \mathrm{C}$ for the 5-day period after application. Nitrogen was likely lost by volatilization during this period.

Summer forage production was reduced by $23 \%$ following dormant-season litter removal (Table 5). These losses probably resulted from changes in the microenvironment on the plots rather than from direct effects of plant defoliation because the litter removal treatment was applied when plants were senescent. Estimates of snow cover taken in late January 1981 indicated that the percent cover of snow on the plots where litter was removed (34\%) was lower $(P<0.05)$ than on the untreated plots $(47 \%)$. This loss of snow cover may have increased frost damage to plants and reduced soil moisture recharge on these plots for spring growth compared
Table 6. Mean herbage yields ( $\mathrm{kg} / \mathrm{ha}$ ) of spring and summer harvested plots as affected by date of $\mathbf{N}$ application.

\begin{tabular}{|c|c|c|c|c|c|c|}
\hline \multirow{2}{*}{$\begin{array}{l}\text { Date } \\
\text { Fertilized }\end{array}$} & \multicolumn{3}{|c|}{ Spring harvest } & \multicolumn{3}{|c|}{ Summer harvest } \\
\hline & 1981 & 1984 & Mean & 1981 & 1984 & Mean \\
\hline & & & . & & & \\
\hline Control & 110 & 242 & $176 \mathrm{~b}$ & 993 & 625 & $809 \mathrm{c}$ \\
\hline Oct. & 156 & 392 & $266 a$ & 1805 & 1216 & 1511 a \\
\hline Nov. & 141 & 362 & 259 a & 1517 & 1289 & $1410 \mathrm{ab}$ \\
\hline Jan. & 138 & 323 & $230 \mathrm{ab}$ & 1548 & 1176 & $1362 \mathrm{ab}$ \\
\hline Feb. & 114 & 491 & $303 \mathrm{a}$ & 1164 & 1102 & $1133 \mathrm{~b}$ \\
\hline Mar. & 110 & 477 & $294 a$ & 1790 & 1393 & 1592 a \\
\hline
\end{tabular}

Means in the same column followed by a different letter are significantly different $(P<0.05)$ with Duncan's Multiple Range test.

to those plots with greater snow cover. Ndawula-Senyimba et al. (1971) found that simulated rainwater penetrated deeper into the soil profile beneath intact bluebunch wheatgrass plants than beneath plants which had been clipped. They attributed the difference to the funnelling effect of the aerial plant parts which directed rainfall into the rooting zone.

Although dormant-season removal of litter reduced summer forage yields, there was no interaction with any other factor. Therefore, true above-ground herbage production can be determined by adjusting treatment means to account for the losses from the litter removal treatment. This technique has the potential to halve the cost of clipping experimental plots which require litter to be sorted from current year's production. For example, an average of $7 \mathrm{~min}$ was required to harvest a plot which had been treated with litter removal compared to $15 \mathrm{~min}$ to harvest an untreated plot.

\section{Conclusions}

Spring forage production was unaffected regardless of whether urea was applied on snow or bare ground but summer yields were reduced when urea was applied on snow. Therefore, in order to maximize returns from fertilization, we recommended that urea be applied only on bare soils.

Autumn litter removal, following plant dormancy, reduced both spring and summer yields. Therefore, preharvesting plots in fall to clear litter is not recommended in studies where spring yields are required and particularly where absolute values of above-ground biomass are required.

Even though summer forage yields were reduced by the fall litter removal, there was no further change in the effect when these plots were fertilized. Therefore, in fertilizer trials at least, this technique may be used to reduce harvesting time of the plots in the next growing season. Corrections will be required, however, to account for losses resulting from the fall litter removal if absolute standing crop is required in the study.

\section{Literature Cited}

Atmosphric Environment Service. 1984. Annual meteorological summary, Environment Canada. Downsview, Ontario.

Campbell, C.A., A.J. Leyshon, H. Ukrainetz, and R.P. Zentner. 1986. Time of application and source of nitrogen fertilizer on yield, quality, nitrogen recovery, and net returns for dryland forage grasses. Can. J. Plant Sci. 66:915-931.

Hubbard, W.A., and J.L. Mason. 1967. Residual effects of ammonium nitrate and ammonium phosphate on some native ranges of British Columbia. J. Range Manage. 20:1-5.

Hull, A.C. Jr. 1963. Fertilization of seeded grasses on mountainous rangelands in northeastern Utah and southeastern Idaho. J. Range Manage. 16:306-310. 
Kllcher, M.R., S. Smolink, W.A. Hubbard, A. Johnaton, A.T.H. Grous, and E.V. MeCurdy. 1965. Effects of inorganic nitrogen and phosphorus fertilizers on selected sites of native grassland in Western Canada. Can. J. Plant Sci. 45:229-237.

MeShane, M.C., and R.H. Sauer. 1985. Comparison of experimental fall burning and clipping on bluebunch wheatgrass. Northwest Sci. 59:313-318.

McLean, A., and L. Marchand. 1968. Grassland ranges in the southern interior of British Columbia. Can. Dep. Agr. Pub. No. 1319. Ottawa, Ontario.

Mason, J.L., and J.E. Miltimore. 1959. Increase in yield and protein content of native bluebunch wheatgrass from nitrogen fertilization. Can. J. Plant Sci. 39:501-504.

Mason, J.L., and J.E. Miltimore. 1964. Effect of nitrogen content of beardless wheatgrass on yield response to nitrogen fertilization. J. Range Manage. 17:145-147.

Mason, J.L., and J.E. Miltimore. 1969. Yield increases from nitrogen on native range in southern British Columbia. J. Range Manage. 22:128-131.

Mason, J.L., and J.E. Miltimore. 1972. Ten year yield response of beardless wheatgrass from a single nitrogen application. J. Range Manage. 25:269-272.
Ndawula- Senyimba, M.S., V.C. Brink, and A. McLean. 1971. Moisture interception as a factor in the competitive ability of bluebunch wheatgrass. J. Range Manage. 24:198-200.

SAS Institute, Inc. SAS User's Gulde 1979 Edition. Cary, NC., 1979.

Sauer, R.H. 1978. Effect of removal of standing dead material on growth of Agropyron spicatum. J. Range Manage. 78:121-122.

Sneva, F.A. 1973. Wheatgrass response to seasonal applications of two nitrogen sources. J. Range Manage. 26:137-139.

Tisdale, E.W. 1947. The grasslands of the southern interior of British Columbia. Ecology 28:346-382.

Tisdale, S.L., and W.L. Nelson. 1975. Soil fertility and fertilizers. Macmillan Publishing Co., Inc. New York.

Willms, W.D., S. Smoliak, and A.W. Bailey. 1986. Herbage production following litter removal on Alberta native grasslands. J. Range Manage. 39:536-540.

Wilson, A.M., G.A. Harris, and D.H. Gates. 1966. Fertilization of mixed cheatgrass-bluebunch wheatgrass stands. J. Range Manage. 19:134-137.

Wullstein, LeRoy H., and C.M. Glmour. 1964. Gaseous nitrogen losses and range fertilization. J. Range Manage. 17:203. 